\title{
AN EXPERIMENTAL METHODOLOGY FOR ARTERIAL WALLS
}

\author{
ANÁLISE EXPERIMENTAL DE PAREDES ARTERIAIS
}

\author{
Ana Bárbara Krummenauer FORMENTON ${ }^{1}$; Jakson Manfredini VASSOLER ${ }^{2}$; \\ Pierre Galvagni SILVEIRA ${ }^{3}$; Carlos Rodrigo de Mello ROESLER ${ }^{3}$ \\ 1. Mestre em Engenharia Mecânica, Universidade Federal do Rio Grande do Sul - UFRGS, Porto Alegre, RS, Brasil. \\ ana.barbara@ufrgs.br; 2. Professor, Doutor, Universidade Federal do Rio Grande do Sul - UFRGS, Porto Alegre, RS, Brasil; 3 \\ Professor, Doutor, Universidade Federal de Santa Catarina - UFSC, Florianópolis, SC, Brasil.
}

\begin{abstract}
Numerical simulations of arterial walls allow a better understanding of the interaction between biological tissue and endoprosthesis (stents), which are used in aneurysms or atherosclerosis stenosis treatment. A reliable understanding of this interaction may help one to select, or even design, the best structure for a given clinical indication. The development of a realistic numerical simulation requires an appropriated definition of a constitutive model and the obtainment of experimental data useful to a parameter identification procedure. Biological tissues have different mechanical characteristics of materials commonly used for engineering applications, however the experimental data acquisition is a major challenge. Some examples of technical difficulties of experimental test in biological tissue are associated to the obtainment of samples, temperature and humidity control during storage, suitable gripping and geometric and strain measurements methods. Therefore, this paper presents an experimental methodology to perform uniaxial mechanical tests in pig arteries in order to provide useful information for material models of arterial walls. This study proposes the experimental procedure from the sample obtainment to the uniaxial experimental testing of the tissue in two directions (circumferential and longitudinal) at two strain rates. In order to shown the use of the experimental data into a suitable numerical model for arterial walls, a parameter identification procedure was performed to obtain material parameters of a viscoelastic anisotropic model with fiber dispersion for finite strains. Through the experimental methodology proposed it was possible to obtain useful data for the parameter identification. Moreover, the results demonstrate that the arterial walls mechanical behavior was properly represented by the selected model.
\end{abstract}

KEYWORDS: Experimental procedure. Arterial walls. Uniaxial tests. Anisotropic viscoelastic model.

\section{INTRODUCTION}

Arteries are blood vessels that carry blood from heart to all parts of the body, carrying nutrients and oxygen (JUNQUEIRA, 2004). The arteries can be divided into elastic and muscular, possessing collagen and elastin as their main constituents, which alongside with other components, are arranged in layers. These layers should provide mechanical strength to stand vessels internal pressures.

Arteries are subject to several pathologies and the major ones are atherosclerosis and aneurysm. These pathologies can be treated by the use of vascular endoprosthesis (stents), which are inserted through surgical interventions. The stent is a metallic or polymeric mesh and may or may not be covered with a tissue. In the past years, the use of these components was widespread. However, the use of stents for pathologies correction can trigger adverse events that may require further surgery intervention. Wrong selection of the stents geometric characteristics can lead to complications. Some of the possible problems are: leakage, device displacement (migration), implant rupture, or arterial wall tissue damage (BLUM et al., 2001,
JACOBS et al., 2003, LI et al., 2006, CORBETT et al., 2008, BOCK et al., 2012, MORRIS et al., 2013).

A better understanding of the interaction between arterial wall and stents can help in the tubular structure design or in the selection of the most suitable stent model for a given clinical indication, as well as aiding the positioning process during a surgical procedure (HOLZAPFEL; GASSER, 2007; BOCK et al., 2012). Therefore, knowing the arterial walls mechanical behavior is necessary in order to obtain a reliable mathematical representation. Due to their composition, the arteries present an anisotropic and strongly nonlinear mechanical behavior. Additionally, they may present fibers mechanical damage when loaded above the physiological deformation region, which is especially truth in some clinical treatments.

The understanding of the stent/arterial wall interaction may be achieved by numerical simulations, which demand appropriated material models to represent the real tissue behavior. The material model, on the other hand, needs useful experimental data to identify the material parameters of the material model. There are several challenges associated with data acquisition for biological tissue. The procedure definition involves 
An experimental methodology...

sample obtainment, temperature and humidity control during the storage stage and specimen handling. The required time for each step must be carefully defined to maintain the mechanical characteristics observed in vivo (HOLZAPFEL; OGDEN, 2009). There are also difficulties associated to the test procedure, such as sample clamping and strain measurements. Sample slippage is common and occurs due to the tissue moisture and stiffness. Moreover, tissue mechanical properties can change from on individual to another or even in the same individual, depending on the region in which the artery is removed.

There are several experimental procedures presented in the literature, notwithstanding there is still no consolidated methodology. Therefore, the present work aims to study and propose an experimental methodology capable to acquire useful experimental data for material models of arterial walls. In this approach the arterial wall is considered a single layer. Despite this study focus in the experimental methodology, it is also performed a parameter identification to obtain material parameters of a viscoelastic anisotropic model with fiber dispersion.

\section{Arterial walls}

The arterial mechanical behavior and the difficulties concerning experimental tests are directly related with the arterials internal structure. According to Junqueira (2004), blood vessels are generally composed by three layers (tunics), the innermost vessel layer is called intima, media is the middle layer and the outermost layer is the adventitia.

According to its structure and size, arteries are classified into elastic, muscle and capillaries arteriole. Elastic arteries, which include aorta, have a greater diameter, higher elastic fibers number and are located at the surrounding of the heart. Muscular arteries have an average diameter. Arterioles have smaller diameter with a few smooth muscle layers and almost none connective tissue.

As presented by Junqueira (2004), depending on the artery classification, the characteristics of each layer can differ. In healthy young individuals, the intima is very thin and has an insignificant contribution to the arterial wall mechanicals strength (HOLZAPFEL et al., 2000). The intima contribution may become meaningful with age (ex.: atherosclerosis occurrence) (HOLZAPFEL et al., 2000). The middle layer (media) provides most of the mechanical resistance necessary to sustain the walls structural integrity
FORMENTON, A. B. K. et al.

(PETERSON; BRONZINO, 2008; HOLZAPFEL et al., 2000).

In addition to the influence of each component in the arteries mechanical properties, the artery location in the body also modifies its properties. However, the general mechanical characteristics exhibited by arterial walls do not change (HOLZAPFEL et al., 2000). As a matter of fact, arterial walls can be characterized in different ways due to its internal organization. It can be mechanically characterized as a single layer, or it can be separate in three layers, where each layer shows different mechanical behavior.

The arterial mechanical behavior can be characterized by appropriate experimental tests, which may be in vivo or in vitro (HOLZAPFEL et al., 2000). Arterial walls behavior involves several mechanical phenomena, which may change due to physiological characteristics. During in vivo tests, one can observe the real physical behavior of an artery under the influence of different factors, such as pulse and hormones. Masson et al. (2008) and Masson et al. (2011) employed noninvasive methods to perform in vivo studies. In vivo tests are hard to conceive, especially if one intends to use its results to characterize a constitutive model. The most commonly tests used in the biological tissues characterization are in vitro tests. These tests are simple, experimentally speaking, and attempt to simulate environmental conditions and physiological loading (or even exceed these conditions). Using in vivo tests, the artery can be fully characterized by imposing specific boundary conditions (HOLZAPFEL et al., 2000).

Among the several possible in vitro tests, one must consider: uniaxial testes (ZHANG; AROLA, 2004; STEMPER et al., 2005), sheer inflation tests (BADER, 1967) and multiaxial tests, also known as extension-inflation tests (KASYANOV et al., 2003, SOMMER et al., 2010; KIM; BAEK, 2011). The test choice is directly dependent to the material model selected to represent the tissues mechanical behavior. This dependency is due the fact that each model requires specific information to work properly. As an example, anisotropic models demand mechanical behavior studies in different directions. Viscous effects, on the other hand, require protocols allowing the study of the mechanical response time dependency. This behavior can be seen in situations such as tests with: creep, relaxation, cyclic or with different speeds excitation. 
An experimental methodology...

\section{Mechanical procedures for arterial walls}

Considering the different factors which can directly influence the tissue response, an appropriate protocol should be followed. These materials have different mechanical characteristics when compared to the commonly used in engineering. Some of the challenges faced when working with these materials are: samples obtainment (geometric uniformity and homogeneous material), storage (humidity, temperature, and degradation time), sample grip (slippage phenomenon), measuring deformation (flexible and wet material) and several others. Therefore, the experimental methodology needs to take into account the above mentioned factors.

\section{Samples Obtainment}

The samples obtainment is usually executed as soon as possible, after animal or human death, thereafter the experimental test or the sample storage are performed. Despite the importance of this factor, few studies mention the postmortem interval that, the samples were collected.

In Beenakker et al. (2012), pig aortas were collected 18 hours after animal slaughter. Zoumi et al. (2004) removed coronary samples, 15 minutes after animal sacrifice. Zhang and Arola (2004) collected samples from a bovine aorta, 30 minutes after animal death. In Holzapfel (2005) abdominal human aorta samples were removed within 24 hours after death.

\section{Storage}

Samples storage should be performed due to the degradation that arteries suffer in ex vivo conditions (HOLZAPFEL et al., 2000). Each author presents the storage procedure in a different way, as well as the temperature which the samples are stored. Beenakker et al. (2012) stored pig aortas at $-80^{\circ} \mathrm{C}$. In Sommer et al. (2010) the carotid bifurcation was frozen at $-80^{\circ} \mathrm{C}$, immediately after excision. In Zemanek et al. (2009) pig thoracic aortas were refrigerated at $-20^{\circ} \mathrm{C}$. Some works, such as Zhang and Arola (2004), and Holzapfel (2005), perform the experimental tests after excision, without freezing.

\section{Defrosting}

After storing the tissue at sub-zero temperatures, the samples need to be defrosted. This process is sometimes not mentioned by the authors, as in Beenakker et al. (2012). In Sommer et al. (2010) the specimens were slowly thawed at $4^{\circ} \mathrm{C}$, prepared at room temperature $\left(20^{\circ} \mathrm{C}\right)$ and then tested.
FORMENTON, A. B. K. et al.

\section{Samples geometric measurement}

Samples geometric measurement procedure may differ a lot, due to the type of test and the necessary measures for tissue characterization. In uniaxial tests the geometric measures are: length and thickness. In Holzapfel and Ogden (2009), length and thickness were optically measured, with video extensometer. In Gundiah et al. (2009) the thickness was measured by a caliper, fitting the sample between two glasses. Zoumi et al. (2004) measured the thickness and diameter through optical microscope. In Stemper et al. (2005) width end thickness was measured with a digital pachymeter.

\section{Sample clamping}

The specimens clamping will depend on the test type to be performed. For inflation and extension tests the samples need to be cannulated at both ends, with specially designed tube connectors, as in the work of Sommer et al. (2010). Gundiah et al. (2009) conducted biaxial tests and the specimens were fixed to the machine with Delrin ${ }^{\circledR}$ clamps. Stemper et al. (2005) developed a gripping device to prevent slippage, which consists of two opposing metal blocks fastened together to fix de inferior and superior ends. In addition, it has a thirty-gauge wire mesh on the inner edges of the blocks to secure the specimen. Zemanek et al. (2009) and Zhang and Arola (2004) fixed the samples with grips. Holzapfel and Ogden (2009) mounted pieces of sandpaper at the ends of the sample with superadhesive gel.

\section{Test class}

In the case of biological tissue, temperature and hydration are important factors. Therefore, the tissue must be hydrated and controlled with a specific temperature, when possible. Holzapfel and Ogden (2009) and Sommer et al. (2010) maintained the specimens in saline solution. In Gundiah et al. (2009) the samples were placed in an acrylic bath tray containing distilled water at $37^{\circ} \mathrm{C}$.

\section{Preconditioning}

The preload and cyclic preconditioning are performed by many authors to align collagen fibers along preferred directions and to restore the specimen in vivo state as much as possible. Different methods are used in the literature. For cyclic stress-strain curves, Holzapfel and Ogden (2009) performed a pre-conditioning through 5 cycles at $1 \mathrm{~mm} / \mathrm{min}$ to the in situ length. Gundiah et al. (2009) executed the preconditioned of samples with 10 cycles up to $10 \%$ stretch in a triangular waveform at $0.05 \mathrm{~Hz}$. In Stemper et al. (2005), the 
An experimental methodology...

specimens were preconditioned with five distraction cycles at $0.1 \mathrm{~mm} / \mathrm{s}$ until approximately in situ length,. In Zemanek et al. (2009) the specimens were preload by a maximum total load of $0.5 \mathrm{~N}$.

\section{Crosshead speed}

Each test reported in the literature employ different load speed. Holzapfel and Ogden (2009) used $1 \mathrm{~mm} / \mathrm{min}$, as well as Sommer et al. (2010). In Stemper et al. (2005), the specimen was quasistatically loaded in tension at $0.1 \mathrm{~mm} / \mathrm{s}$, until ultimate failure of the vessel.
FORMENTON, A. B. K. et al.

\section{MATERIAL AND METHODS}

\section{Experimental methodology}

Based on literature and equipment availability, it was possible to propose a methodology to perform experimental tests attempting to capture the tissue anisotropic mechanical behavior. One can follow different procedures combinations. Some of the alternatives are summarized in Table 1.

Table 1. Tests alternatives.

I. Sample collect :

- 15 minutes after animal sacrifice (ZOUMI et al., 2004);

- 30 minutes after animal death (ZHANG and AROLA, 2004);

- 18 hours after animal slaughter (BEENAKKER et al., 2012);

- within 24 hours after death (HOLZAPFEL, 2005).

II. Storage (as necessary):

- $\quad-80^{\circ} \mathrm{C}$ (BEENAKKER et al., 2012, SOMMER et al., 2010)

- $-20^{\circ} \mathrm{C}$ (ZEMANEK et al., 2009)

III. Defrosting:

- slowly, first at $4^{\circ} \mathrm{C}$ and then at room temperature (SOMMER et al., 2010);

- quickly, at room temperature, with saline solution (WILCHEZ, 2012);

- quickly, at room temperature, without saline solution;

IV. Samples geometric measurement before cutting:

Length and width:

- optically, with video extensometer (HOLZAPFEL and OGDEN, 2009);

- digital pachymeter (STEMPER et al., 2005);

Thickness:

- caliper, fitting the sample between two glasses (GUNDIAH et al., 2009);

- digital pachymeter (STEMPER et al., 2005);

- optically, through optical microscope (ZOUMI et al., 2004), video extensometer (HOLZAPFEL and OGDEN, 2009) or BOSE 3330 equipment;

Diameter:

- outside, through video extensometer (SCHULZE-BAUER et al., 2002), diameter template (WILCHEZ, 2012) or BOSE 3330 equipment;

- inside, through optical microscope (ZOUMI et al., 2004);

- digital pachymeter;

V. Sample cut:

- using a scalpel in rectangular shape;

- with cut device into dumbbell shape.

VI. Samples geometric measurement after cutting:

Length and width:

- optically, with video extensometer (HOLZAPFEL and OGDEN, 2009);

- digital pachymeter (STEMPER et al., 2005); 
Thickness:

- calipers, by gently sandwiching the specimen between two glass slides (GUNDIAH et al., 2009);

- digital caliper (STEMPER et al., 2005);

- optically, through optical microscope (ZOUMI et al., 2004), videoextensometer (HOLZAPFEL and OGDEN, 2009) or BOSE 3330 equipment;

VII. Sample clamping :

- clamps (GUNDIAH et al., 2007, ZEMANEK et al., 2009);

- compression grips (ZHANG and AROLA, 2004);

- gripping device developed to prevent slippage, through thirty-gauge wire mesh on the inner edges of the blocks to secure the specimen (STEMPER et al., 2005);

- mount pieces of sandpaper at the ends of the sample with super adhesive gel (HOLZAPFEL and OGDEN, 2009);

VIII. Test class:

- in solution $-37^{\circ} \mathrm{C}$ (GUNDIAH et al., 2009, ZEMANEK et al., 2009);

- moistureless (HOLZAPFEL and OGDEN, 2009, SOMMER et al., 2010);

IX. Crosshead speed:

- $0.1 \mathrm{~mm} / \mathrm{s}$ (STEMPER et al., 2005);

- $1 \mathrm{~mm} / \mathrm{min}$ (HOLZAPFEL and OGDEN, 2009, SOMMER et al., 2010);

- $5 \mathrm{~mm} / \mathrm{min}$

- $10 \mathrm{~mm} / \mathrm{min}$;

X. Preconditioning:

- maximum total load 0,5N (ZEMANEK et al., 2009);

- without preloading;

- 5 distraction cycles at $0.1 \mathrm{~mm} / \mathrm{s}$ to approximately the in situ length (STEMPER et al., 2005);

- 5 cycles at $1 \mathrm{~mm} / \mathrm{min}$ to the in situ length (HOLZAPFEL and OGDEN, 2009);

- 6 cycles at $0,1 \mathrm{~mm} / \mathrm{min}$ up to 0,3 MPa (ZEMANEK et al., 2009);

- 10 cycles up to $10 \%$ stretch in a triangular waveform at $0.05 \mathrm{~Hz}$ (GUNDIAH et al., 2009);

- without pre-conditioning.

Considering the alternatives presented in literature (Table 1), and pilot tests performed in laboratory, a final procedure was defined:

1. Immediately after artery removal, the diameter is measured along the length of the blood vessel.

2 . The sample is wrapped in a damp cloth and stored in a plastic bag at $-20^{\circ} \mathrm{C}$ (if required).

3. Defrost the tissue at refrigerated ambient or room temperature (if required).

4. Maintain the arterial wall in saline solution until sample cut.

5. Diameter measuring along the length of the blood vessel.

6. Select a region with uniform diameter and perform a longitudinal cut.

7. From the selected cut, perform longitudinal (or/and transverse) cuts to obtain samples.
8. Fix the sample on the clamp. Ensure that the sample is aligned and verify if it is tight enough to prevent slippage, but not enough to crush the sample.

9. Preload at $0.5 \mathrm{~N}$. Employ a velocity of $5 \mathrm{~mm} / \mathrm{min}$ until $0.5 \mathrm{~N}$, wait for the appointed time.

This procedure can be adapted for different circumstances. Steps 2 and 3 are required only when the experimental test cannot be performed immediately after obtainment of the blood vessel. The selection of the blood vessel region to obtain arterial walls samples is important due to the fact that the blood vessel changes considerably its geometry and thickness along its length. If two samples are collected from the same vessel, but from different positions (extremities, for instance), it is expected different mechanical behaviors since the vessel is a nonhomogeneous material. Then, it is 
important to select a region with uniform geometrical characteristics in order to obtain the tissue samples for mechanical tests.

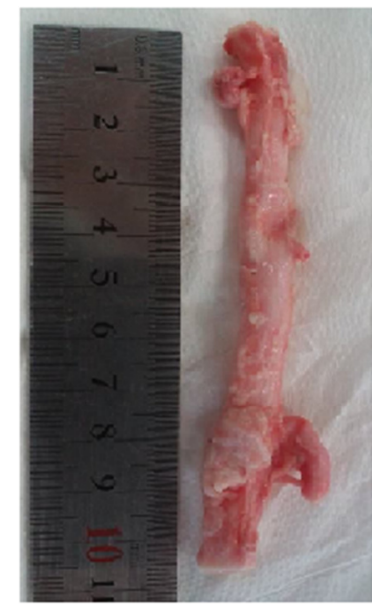

Figure 1. (a) Blood vessels; (b) ar

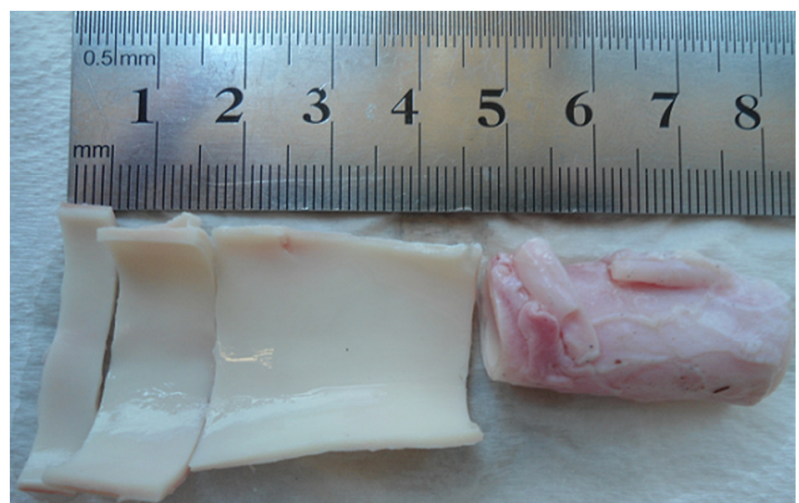

(b)
Finally, it is possible to perform experimental tests. The quantity of mechanical test depends of the mechanical characteristics of the material and the choice of the material model. An isotropic elastic model needs only one uniaxial test to obtain their material parameters. An anisotropic elastic model may require more tests if no information about fiber direction is previously known. As a general rule, the complexity of material model in its capability to take into account different internal phenomena is directly related to the quantity of their material parameters and, consequently, to the quantity of experimental tests needed to characterize it.

In this study an anisotropic viscoelastic model was chosen. In order to obtain useful data to perform material parameter identification, two monotonic uniaxial tests were performed at $1 \mathrm{~mm} / \mathrm{min}$ and at $5 \mathrm{~mm} / \mathrm{min}$ and one cyclic uniaxial test at $1 \mathrm{~mm} / \mathrm{min}$ for the longitudinal and circumferential direction of the arterial wall. The quantity of tests was chosen due the quantity of samples obtained from an aorta of healthy Landrace pigs (Figure 1), which is a limiting. This artery had significant changes in their geometrical characteristic, displaying significant thickness variations along the arterial wall. In order to deal with this adversity, it was decided to use samples from the same region.

Using the procedure defined previously, the artery was removed and stored in a refrigerator at $1.8^{\circ} \mathrm{C}$ for one day. Immediately before the tests execution, the artery was placed in saline solution at room temperature $\left(\approx 24^{\circ} \mathrm{C}\right)$. The aorta was sectioned with a scalpel and the uniform regions were selected, as illustrated in Figure 1(b). The geometrical dimensions of the samples were defined with a $25 \mathrm{~mm}$ length and $5 \mathrm{~mm}$ width of. It should be noted that these dimensions may change for other blood vessels. The thickness was measured with a BOSE optical measurement system along the sample length. The average thicknesses are presented in Table 2. The samples were clamped by screw grips especially developed for this test. Furthermore, it was used a preconditioning with a pre-load of $0.5 \mathrm{~N}$.

Table 2. Samples average thickness (and standard deviation).

\section{Conducted tests}

Longitudinal monotonic test $1 \mathrm{~mm} / \mathrm{min}$

Circumferential monotonic test $1 \mathrm{~mm} / \mathrm{min}$

Longitudinal monotonic test $5 \mathrm{~mm} / \mathrm{min}$

Circumferential monotonic test $5 \mathrm{~mm} / \mathrm{min}$

Longitudinal cyclic test $1 \mathrm{~mm} / \mathrm{min}$

Circumferential cyclic test $1 \mathrm{~mm} / \mathrm{min}$

\section{Thickness (standard deviation)}
$2.1 \pm 0.22 \mathrm{~mm}$
$1.73 \pm 0.11 \mathrm{~mm}$
$1.68 \pm 0.04 \mathrm{~mm}$
$1.453 \pm 0.34 \mathrm{~mm}$
$2.106 \pm 0.09 \mathrm{~mm}$
$1.41 \pm 0.17 \mathrm{~mm}$ 


\section{RESULTS AND DISCUSSION}

\section{Experimental results}

Following the presented experimental methodology, the load-displacement curves were obtained. The monotonic test results for the longitudinal and circumferential directions, at 1
FORMENTON, A. B. K. et al.

$\mathrm{mm} / \mathrm{min}$ and $5 \mathrm{~mm} / \mathrm{min}$, are presented in Figure 2. A load-displacement curve for cyclic test for longitudinal and circumferential directions, at 1 $\mathrm{mm} / \mathrm{min}$, is presented in Figure 3(a). The samples were loaded until the rupture or full slippage (Figure $3(\mathrm{~b}))$.

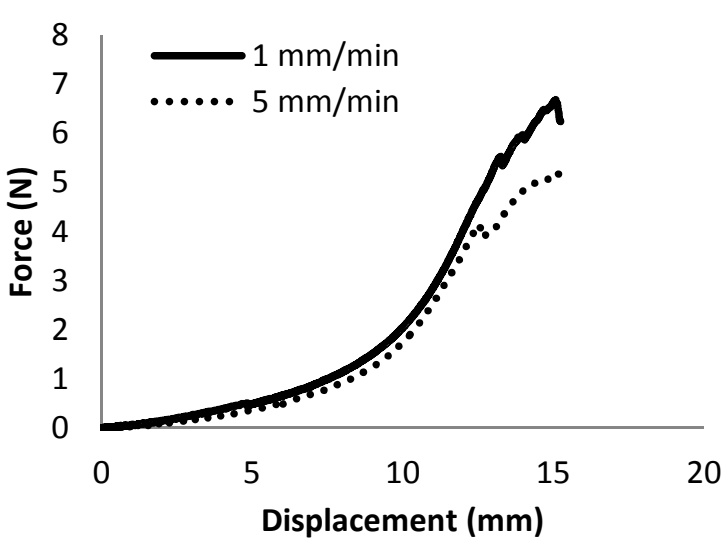

Figure 2. Monotonic tests: circumferential direction (left) and longitudinal direction (right).

It can be seen that the monotonic and cyclic tests were performed with very high loadings, being possible to observe a similar phenomenon to that of mechanical damage in the cyclic response.
In this case the cyclic curves (Figure 3(a)) are similar to the Mullins effect, as expected (HOLZAPFEL, 2000).

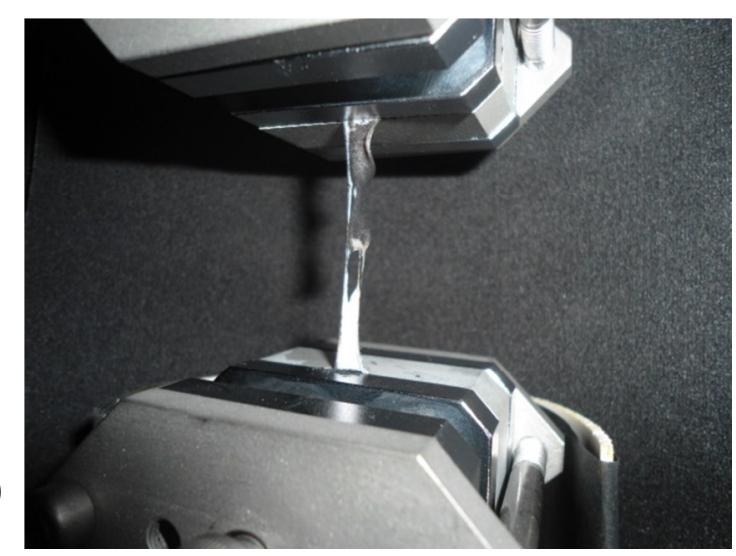

(b)

Figure 3. (a) Cyclic tests; (b) Experimental test.

Arterial tissue characterization requires the obtainment of uniaxial stress-strain curves using procedures analogous to the ones used with other materials.

\section{Model used to parameters identification}

In order to exemplify the use of the experimental data, an anisotropic model with fiber dispersion for arterial walls, proposed by Gasser et al. (2006) was used. This model is based on
Holzapfel et al. (2000). For the present study the isotropic part was modified to include viscoelastic effects.

In the model proposed by Gasser et al. (2006) there is an isotropic $\bar{\Psi}_{\text {iso }}$ and one anisotropic $\bar{\Psi}_{\text {aniso }}$ part. The anisotropic part takes into account the fiber contribution. In this model is assumed the existence of two families of collagen fibers and the strain energy is given by:

$\bar{\Psi}\left(\overline{\boldsymbol{C}}, \boldsymbol{a}_{01}, \boldsymbol{a}_{02}\right)=\bar{\Psi}_{\text {iso }}\left(\bar{I}_{1}, \bar{I}_{2}\right)+\bar{\Psi}_{\text {aniso }}\left(\bar{I}_{4}, \bar{I}_{6}\right)$ 
where $\overline{\mathrm{I}}_{4}=\mathbf{a}_{01} \cdot \overline{\mathbf{C}} \mathbf{a}_{01}$ and $\overline{\mathrm{I}}_{6}=\mathbf{a}_{02} \cdot \overline{\mathbf{C}} \mathbf{a}_{02}$ are pseudo-invariant deformation (HOLZAPFEL et al, 2000), $\mathbf{a}_{01}$ and $\mathbf{a}_{02}$ are unit vectors that indicate the two fiber families' directions, $\overline{\mathbf{C}}=\mathrm{J}^{-2 / 3} \mathbf{C}$ is the right Cauchy-Green strain tensor modify and $\mathrm{J}$ is the Jacobian. In this model $\overline{\mathrm{I}}_{6}$ and $\overline{\mathrm{I}}_{4}$ only differ in fiber direction (HOLZAPFEL et al, 2000). $\overline{\mathrm{I}}_{1}$ and $\overline{\mathrm{I}}_{2}$ are respectively the first and second isochoric deformation-invariant.

The isotropic part allows using different models, in here will be used Mooney-Rivlin model,

$\bar{\Psi}_{\text {iso }}\left(\bar{I}_{1}, \bar{I}_{2}\right)=\frac{c_{1}}{2}\left(\bar{I}_{1}-3\right)+\frac{c_{2}}{2}\left(\bar{I}_{2}-3\right)$

where $c_{1}$ and $c_{2}$ are material constants.

The anisotropic part, which includes fiber's dispersion effects in the direction, is given by:

$\bar{\Psi}_{\text {aniso }}\left(\bar{I}_{4}, \bar{I}_{6}\right)=\frac{k_{1}}{2 k_{2}} \sum_{i=4,6}\left\{\exp \left[k_{2}\left(\kappa \bar{I}_{1}+\right.\right.\right.$

$\left.\left.\left.(1-3 \kappa) \bar{I}_{4}-1\right)^{2}\right]-1\right\}$

where $k_{1}>0$ is a stress-like material parameter, $k_{2}>0$ is a dimensionless parameter and $\kappa$ is the dispersion (structure) parameter. The correct selection of $k_{1}$ and $k_{2}$ allows that the collagen fibers do not affect the artery mechanical response, at low pressures, to be represented (ROACH; BURTON, 1957, apud HOLZAPFEL et al., 2000). To ensure that the fibers do not contribute when subjected to compressive deformation, the following restrictions are imposed: $\bar{I}_{4} \geq 1$ and $\bar{I}_{6} \geq 1$.

The isochoric Cauchy stress tensor is given by:

$$
\begin{aligned}
& \bar{\sigma}=2 J^{-1}\left(\frac{\partial \Psi}{\partial \bar{I}_{1}}+\bar{I}_{1} \frac{\partial \Psi}{\partial \bar{I}_{2}}\right) \overline{\boldsymbol{b}}-2 J^{-1} \frac{\partial \Psi}{\partial \bar{I}_{2}} \overline{\boldsymbol{b}}^{2}+ \\
& \sum_{i=4,6} 2 \bar{\Psi}_{i} \operatorname{dev}\left(\boldsymbol{a}_{i} \otimes \boldsymbol{a}_{i}\right)
\end{aligned}
$$

where $\overline{\mathbf{b}}$ is the left Cauchy-Green isochoric strain tensor, $\bar{\Psi}_{4}=\partial \bar{\Psi}_{\text {aniso }} / \partial \bar{I}_{4}$ and $\bar{\Psi}_{6}=\partial \bar{\Psi}_{\text {aniso }} / \partial \bar{I}_{6}$ are scalar values.

Viscous effects were included in the isotropic part using the incremental algorithm proposed by Simo (1998). Only one Maxwell's arm was used in the viscoelastic model for large strains. Thus, the isotropic stress expression considering viscous effects is given by:

$\overline{\boldsymbol{S}}=\overline{\boldsymbol{S}}^{o}+J^{-\frac{2}{3}} D E V\left[\sum_{i=1}^{2} \boldsymbol{Q}_{i}(t)\right]$

where $\boldsymbol{Q}_{i}$ are the internal variables.
The evolution of each internal variable $\boldsymbol{Q}_{i}(t)$ is ruled by:

$$
\begin{gathered}
\dot{\boldsymbol{Q}}_{i}(t)+\frac{1}{\tau} \boldsymbol{Q}_{i}(t)=\frac{\gamma}{\tau} D E V\left\{2 \partial_{\overline{\boldsymbol{C}}} \bar{\Psi}^{o}[\overline{\boldsymbol{C}}(t)]\right\} \\
\lim _{t \rightarrow-\infty} \boldsymbol{Q}_{i}(t)=0
\end{gathered}
$$

where $\gamma$ and $\tau$ are material parameters. For more details, see Simo (1998).

Performing this simple modification is possible to obtain an anisotropic viscoelastic model with more flexibility to represent the arterial walls mechanical behaviour.

\section{Parameters identification}

Through the data obtained from uniaxial tests (longitudinal strain and longitudinal stress) is possible to characterize the arterial wall mechanical behaviour considering incompressibility restriction.

As the model used in this study is anisotropic, and the fiber families are not in the same direction of the longitudinal strain, the transversal strains have different magnitudes in the uniaxial testing. Therefore, the finite element method was used to evaluate uniaxial stress.

The constitutive model constants can be obtained through the experimental results using optimization techniques to minimize the difference between experimental and numerical results. The objective function is given by:

$F_{o b j}=\sum_{i=1}^{N}\left(\boldsymbol{\sigma}^{n u m}(\boldsymbol{p})-\boldsymbol{\sigma}^{\text {exp }}\right)^{2}$

where $\boldsymbol{\sigma}^{\text {num }}$ is the vector with the numerically calculated stresses, $\boldsymbol{\sigma}^{\text {exp }}$ is the vector of experimentally obtained stresses and $\mathbf{p}$ is the vector with material model parameters to be found.

The parameters to be identiffed in the selected material model are: $c_{1}$ and $c_{2}$, corresponding to the Mooney-Rivlin parameter, $k_{l}$ and $k_{2}$, anisotropic parameters from Holzapfel et al. (2000), $\gamma$ and $\tau$ corresponding to viscoelasticity, the fiber angle and the dispersion coefficient. Four curves were used simultaneously in the minimization, two in the uniaxial direction (longitudinal and circumferential) with two loading speeds.

The results of the parameter identification procedure are presented in Table 3,(5)hile the numerical and experimental stress-strain curves are illustrated in Figure 4. 
Table 3. Material Parameters

\begin{tabular}{cc}
\hline Parameters & values \\
\hline$c_{1}$ & -193.4 \\
$c_{2}$ & 387.9 \\
$k_{1}$ & 1194.7 \\
$k_{2}$ & 0.011 \\
$\gamma_{1}$ & 0.887 \\
$\tau_{1}$ & 203.3 \\
Fiber angle & 34.6 \\
Dispersion coefficient & 0.293 \\
\hline
\end{tabular}

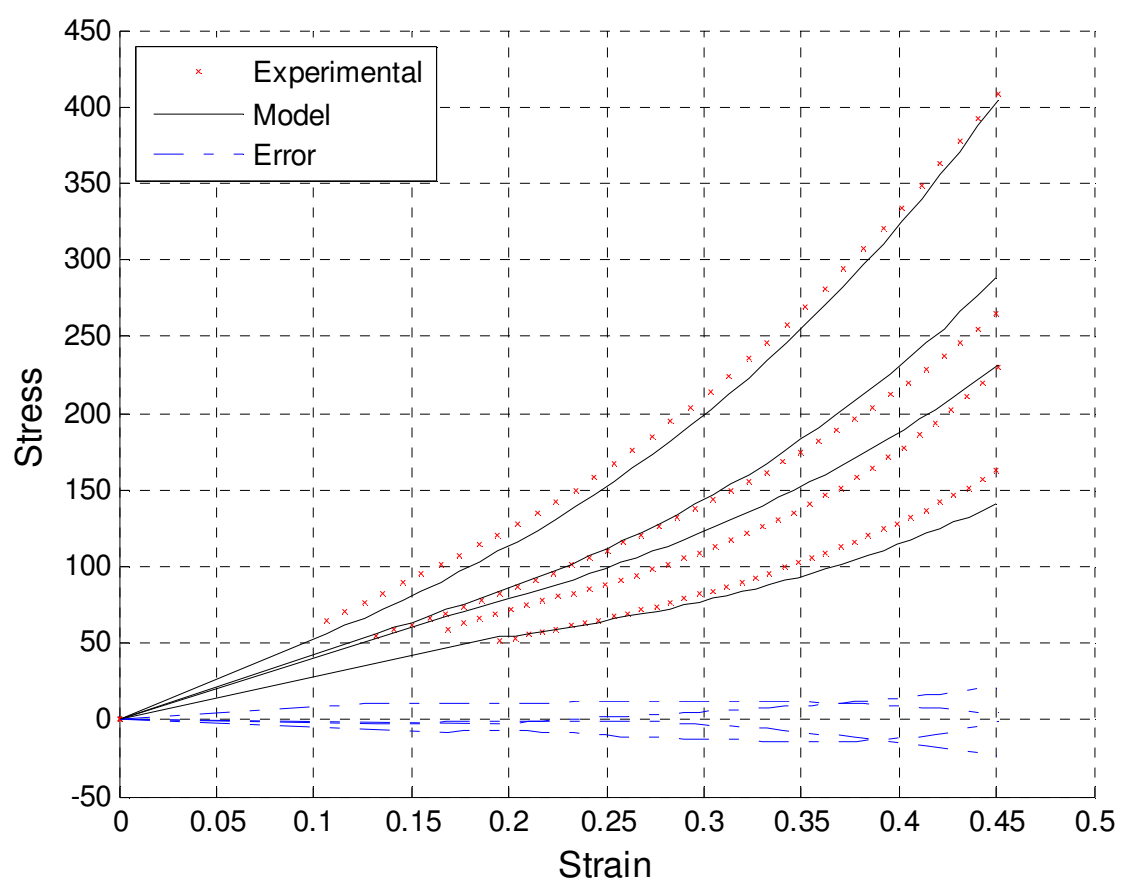

Figure 4. Numerical and experimental stress-strain curves.

\section{CONCLUSIONS}

Realistic numerical simulations of arterial walls require an appropriated constitutive model and useful experimental data. The experimental procedure for these materials still represents a major challenge due the characteristics of biological tissues. This paper proposed an experimental methodology in order to reduce possible problems related to technical difficulties commonly found in experimental tests of arterial walls, such as the obtainment of samples, temperature and humidity control during storage, suitable gripping and geometric and strain measurements methods. This methodology was based on an extensive literature review and practical tests conducted in laboratory during the last years.

With this methodology, uniaxial tests were proposed in order to provide useful information for typical material models of arterial walls. In order to verify the capability of the experimental data to provide useful information for an anisotropic viscoelastic model, a parameter identification procedure was performed to obtain material parameters. In this study monotonic and cyclic uniaxial test in two directions (circumferential and longitudinal) at two strain rates were performed, which were able to reproduce the main characteristics of the selected model. Through the experimental methodology proposed, it was possible to obtain useful data for the parameter identification where it was possible to provide information to represent anisotropic response, as well viscoelastic behavior. The experimental methodology proved effective. However, the employed constitutive model was not able to produce results with the expected quality. 
RESUMO: Simulações numéricas de paredes arteriais permitem um melhor entendimento da interação entre tecido biológico e endopróteses (stents), os quais são utilizados no tratamento de aneurismas e lesões obstrutivas ateroscleróticas. O melhor entendimento desta interação pode auxiliar na seleção do modelo ou no projeto da estrutura da endoprótese mais adequada para uma dada indicação clínica. A realização de simulações numéricas realísticas requer a definição apropriada de um modelo constitutivo e a obtenção de dados experimentais adequados para um procedimento de identificação de parâmetros. Diferentemente dos materiais usados comumente em engenharia, a aquisição de dados experimentais de tecidos biológicos representa um grande desafio. Alguns exemplos das dificuldades técnicas associadas aos testes experimentais de tecidos biológicos estão na obtenção de amostras, no controle de temperatura e humidade durante o armazenamento, na fixação adequada e na medição geométrica e de deformações. Portanto, o presente artigo apresenta uma metodologia experimental para realização de testes uniaxiais em artérias suínas, visando fornecer informações adequadas para modelos materiais de paredes arteriais. Este estudo propõe um procedimento experimental que abrange desde a obtenção da amostra até o ensaio uniaxial do tecido em duas direções (circunferencial e longitudinal), com duas taxas de velocidades. Para exemplificar o uso dos dados experimentais em um modelo numérico adequado para paredes arteriais, um procedimento de identificação de parâmetros foi realizado, obtendo parâmetros materiais de um modelo viscoelástico anisotrópico com dispersão de fibras para deformações finitas. Através da metodologia experimental proposta foi possível obter dados úteis para identificação de parâmetros. Além disso, os resultados demonstraram que o comportamento mecânico de paredes arteriais foi representado adequadamente pelo modelo selecionado.

PALAVRAS-CHAVE: Procedimento experimental. Paredes arteriais. Testes uniaxiais. Modelo viscoelástico anisotrópico.

\section{REFERENCES}

BADER, H. Dependence of Wall Stress in the Human Thoracic Aorta on Age and Pressure, Circulation Research, V. XX, 1967.

BEENAKKER, J. M., ASHCROFT, B. A., LINDEMAN, J. H. N., OOSTERKAMP, T. H. Mechanical Properties of the Extracellular Matrix of the Aorta Studied by Enzymatic Treatments. Biophysical Journal, v. 8, p. 1731-1737, 2012. http://dx.doi.org/10.1016/j.bpj.2012.03.041

BLUM, U., HAUER, M., PFAMMATTER, T., VOSHAGE, G. Percutaneous Endoprosthesis for Treatment of Aortic Aneurysms. World Journal of Surgery, v. 25, n. 3, 2001.

BOCK, S., IANNACCONE, I., SANTIS, G., BEULE, M., MORTIER, P., VERHEGGHE, B., SEGERS, P. Our capricious vessels: The influence of stent design and vessel geometry on the mechanics of intracranial aneurysm stent deployment. Journal of Biomechanics, v. 45, p. 1353-1359, 2012.

http://dx.doi.org/10.1016/j.jbiomech.2012.03.012

CORBETT, T. J., CALlANAN, A., MORRIS, L. G., DOYLE, B. J., GRACE, P. A., KAVANAGH, E. G., Mcgloughlin, T. M. A Review of the In Vivo and In Vitro Biomechanical Behavior and Performance of Postoperative Abdominal Aortic Aneurysms and Implanted Stent-Grafts. Journal of Endovascular Therapy, v. 15, p. 4668-484, 2008. http://dx.doi.org/10.1583/08-2370.1

GASSER, T. C., OGDEN, R. W., HOLZAPFEL, G. A. Hyperelastic modeling of arterial layers with distributed collagen fibre orientations. Journal of the Royal Society Interface, v. 3, p. 15-35, 2006.

http://dx.doi.org/10.1098/rsif.2005.0073

GUNDIAH, N., RATCLIFFE, M. B., PRUITT, L. A. Determination of strain energy function for arterial elastin: Experiments using histology and mechanical tests. Journal of Biomechanics, v. 40, p. 586-594, 2007. http://dx.doi.org/10.1016/j.jbiomech.2006.02.004

GUNDIAH, N., RATCLIFFE, M. B., PRUITT, L. A. The biomechanics of arterial elastin. Journal of the Mechanical Behavior of Biomedical Materials, 2:288-296, 2009.

http://dx.doi.org/10.1016/j.jmbbm.2008.10.007 
HOLZAPFEL, G. A. Nonlinear Solid Mechanics. A Continuum Approach for Engineering. John Wiley \& Sons, LTDA, Inglaterra, 2000.

HOLZAPFEL, G. A., GASSER, T. C., OGDEN, R. W. A new constitutive framework for arterial wall mechanics and a comparative study of material models. Journal of Elasticity, v. 61, p. 1-48, 2000. http://dx.doi.org/10.1023/A:1010835316564

HOLZAPFEL, G. A. Determination of material models for arterial walls from uniaxial extension tests and histological structure. Journal of Theoretical Biology, v. 238, p. 290-302, 2005.

http://dx.doi.org/10.1016/j.jtbi.2005.05.006

HOLZAPFEL, G. A., GASSER, T. C. Computational stress-deformation analysis of arterial walls including high-pressure response. International Journal of Cardiology, v. 116, p. 78-85, 2007.

http://dx.doi.org/10.1016/j.ijcard.2006.03.033

HOLZAPFEL, G. A., OGDEN, R. W., editors. Biomechanical Modelling at Molecular, Cellular and Tissue Levels. Springer Wien, NewYork, 2009.

JACOBS, T. S., Won, J., GRAVEREAUX, E. C., FARIES, P. L., MORRISSEY, N., TEODORESCU, V. J., HOLLIER, L. H., MARIN, M. L. Mechanical failure of prosthetic human implants: A 10-year experience with aortic stent graft devices. Journal of Vascular Surgery, v. 37, p. 16-26, 2003.

http://dx.doi.org/10.1067/mva.2003.58

JUNQUEIRA, L. C., CARNEIRO, J. Histologia Básica. Guanabara Koogan S.A, 2004.

KASYANOV, V., OZOLANTA, I., PURINYA, B., OZOLS, A., KANCEVICH, V. Compliance of a biocomposite vascular tissue in longitudinal and circumferential directions as a basis for creating artificial substitutes. Mechanics of Composite Materials, V. 39, n. 4, 2003.

http://dx.doi.org/10.1023/A:1025698628850

KIM, J., BAEK, S. Circumferential variations of mechanical behavior of the porcine thoracic aorta during the inflation test. Journal of Biomechanics, v. 44, p. 1941-1947, 2011.

http://dx.doi.org/10.1016/j.jbiomech.2011.04.022

LI, Z., KLEINSTREUER, C. Analysis of biomechanical factors affecting stent-graft migration in an abdominal aortic aneurysm model. Journal of Biomechanics, v. 39, p. 2264-2273, 2006.

http://dx.doi.org/10.1016/j.jbiomech.2005.07.010 http://dx.doi.org/10.1016/j.jbiomech.2005.09.002

MASSON, I., BOUTOUYRIE, P., LAURENT, S., HUMPHREY, J. D., ZIDI, M. Characterization of arterial wall mechanical behavior and stresses from human clinical data. Journal of Biomechanics, v. 41, p. 26182627 2008. http://dx.doi.org/10.1016/j.jbiomech.2008.06.022

MASSON, I., BEAUSSIER, H., BOUTOUYRIE, P., LAURENT, S., HUMPHREY, J. D., ZIDI, M. Carotid artery mechanical properties and stresses quantified using in vivo data from normotensive and hypertensive humans. Biomechanics and Modeling in Mechanobiology, v. 10, p. 867-882, 2011. http://dx.doi.org/10.1007/s10237-010-0279-6

MORRIS, L., STEFANOV, F., MCGLOUGHLIN, T. X. Stent graft performance in the treatment of abdominal aortic aneurysms: The influence of compliance and geometry. Journal of Biomechanics, v. 46, p. 383-395, 2011. http://dx.doi.org/10.1016/j.jbiomech.2012.11.026

PETERSON, D. R., BRONZINO, J. D. Biomechanics. Taylor \& Francis Group, 2008.

ROACH, M. R.; BURTON, A. C. The reason for the shape of the distensibility curves of arteries. Canadian journal of biochemistry and physiology, v. 35, n. 8, p. 681-690, 1957. http://dx.doi.org/10.1139/o57-080 
SCHULZE-BAUER, C. A. J., REGITNIG, P., HOLZAPFEL, G. A. Mechanics of the human femoral adventitia including the high-pressure response. American Journal of Physiology, 282:H2427-H2440, 2002. http://dx.doi.org/10.1152/ajpheart.00397.2001

SIMO, J. C. Computational inelasticity. Springer, New York, 1998.

SOMMER, G., REGITNIG, P., KÖLTRINGER, L., HOLZAPFEL, G. A., X. Biaxial mechanical properties of intact and layer-dissected human carotid arteries at physiological and supraphysiological loadings. American Journal of Physiology Heart and Circulatory Physiology, 298:H898-H912, 2008.

http://dx.doi.org/10.1152/ajpheart.00378.2009

STEMPER, B. D., YOGANANDAN, N., PINTAR, F. A. Methodology to study intimal failure mechanics in human internal carotid arteries. Journal of Biomechanics, v. 38, p. 2491-2496, 2005.

http://dx.doi.org/10.1016/j.jbiomech.2004.10.021

WILCHEZ, D. F. T. Estudo do comportamento mecânico de ligamentos e tendões através de uma metodologia com utilização de medição ótica. 2012. Dissertação (Mestrado em Engenharia Mecânica) Curso de Pós- Graduação em Engenharia Mecânica, Federal University of Santa Catarina, Florianópolis, 2012.

ZEMÁNEK, M., BURSA, J., DETÁK, M. Biaxial tension tests with soft tissues of arterial wall. Journal of Engineering Mechanics, v. 16, n. 1, 2009, p. 3-11.

ZHANG, D., AROLA, D. D., X. Applications of digital image correlation to biological tissues. Journal of Biomedical Optics, v. 9, p. 691-699, 2009. http://dx.doi.org/10.1117/1.1753270

ZOUMI, A., Lu, X., KASSAB, G. S., TROMBERG, B. J. Imaging coronary artery microstructure using second-harmonic and two-photon fluorescence microscopy. Biophysical Journal, v. 87, p. 2778-2786, 2004. http://dx.doi.org/10.1529/biophysj.104.042887 